\section{Australian Journal of \\ Crop Science}

\title{
Phosphorus fertilization with enhanced efficiency in soybean and corn crops
}

\author{
Luiz A. Zanão $\mathrm{Jr}^{1}$, Orivaldo Arf ${ }^{2}$, Roberto dos A. Reis $\mathrm{Jr}^{3}$, Natalia Pereira ${ }^{4 *}$ \\ ${ }^{1}$ Agronomic Institute of Paraná, Soils Area, Santa Tereza do Oeste, Paraná, Brazil \\ ${ }^{2}$ São Paulo State University (UNESP), Department of Plant Science, Food Technology and Social Economy, Ilha \\ Solteira, State of São Paulo, Brazil \\ ${ }^{3}$ Wirstchat Polímeros do Brasil, Londrina, PR, Brazil \\ ${ }^{4}$ Western Paraná State University, Department of Agricultural Engineering, Cascavel, Brazil
}

\section{*Corresponding author:}

\begin{abstract}
Due to the low natural availability of phosphorus $(P)$ in tropical soils and the plant's need for $P$, the use of phosphorus fertilizers of increased efficiency is an important tool for achieving high yields. The aims of this study were to evaluate plant growth, foliar $P$ content and yield of soybean and corn crops in different seasons and places in response to $P$ rates and sources. The sources of $P$ were monoammonium phosphate (MAP) and Policote coated MAP (Policote+MAP). Field experiments were carried out comparing MAP performance compared to Policote coated MAP (MAP+Policote), an additive based on water soluble polymers. Experiments formed by $\mathrm{P}$ sources (MAP including $11 \% \mathrm{~N}, 52 \% \mathrm{P}_{2} \mathrm{O}_{5}$ and $\mathrm{MAP}+$ Policote including $10 \% \mathrm{~N}, 49 \% \mathrm{P}_{2} \mathrm{O}_{5}$ ) and rates were carried out in soybean and corn crops in different dates and sites. In the soybean crop, a (2x4) +1 factorial was used, comprising of two sources such as MAP and MAP+Policote and four rates of $P\left(30,60,90\right.$ and $120 \mathrm{~kg} \mathrm{ha}^{-1}$ of $\left.\mathrm{P}_{2} \mathrm{O}_{5}\right)$, besides the control. For corn, a (2x5) factorial was used, including two sources and five rates of $P\left(0,40,80,120\right.$ and $160 \mathrm{~kg} \mathrm{ha}^{-1}$ of $\left.\mathrm{P}_{2} \mathrm{O}_{5}\right)$. The results showed that phosphorus fertilization would increase soybean and corn plant heights and yields in different seasons and places. Soybean and corn yield and agronomic phosphorus use efficiency were higher with Policote coated phosphorus fertilizer than with conventional phosphorus fertilizer. Policote coated phosphorus fertilizer can be used as an enhanced efficiency fertilizer because it increased soybean and corn yields in different seasons and places.
\end{abstract}

Keywords: Policote, agronomic efficiency, field experiments, tropical soils, crop yield.

\section{Introduction}

Plants do not complete their productive cycle without phosphorus $(P)$ because $P$ is an important nutrient in energy storage (ATP) and in the structural integrity (nucleic acids, phospholipids) of plants (Taiz and Zeiger, 2009). However, the inefficient use of $P$ in the form of fertilizer increases pollution and costs on agricultural crops. Developing more efficient $P$ fertilizers is essential for sustainable agriculture. Brazilian soils have very low levels of $P$ due to their source material and the strong interaction of $P$ with soil clays (Raij, 2011). As a result, in tropical soils, the application of $P$ at high doses and above plants' needs is common. This is due to the high adsorption of this nutrient in the soil, resulting in low $\mathrm{P}$ content available to plants, especially in soils with predominant sesquioxides (Fink et al., 2014).

Phosphorus mineral fertilizer is produced from nonrenewable sources (phosphate rocks) and its cost represents an increasing percentage in agricultural production. In addition, low use efficiency in agriculture generates an unsustainable condition. The low efficiency of $P$ fertilization has been reported in different papers (Dorahy et al., 2008; Takashi and Anwar, 2007; Murphy and Sanders, 2007; Sanders et al., 2012).
It is estimated that the plants absorb only 15 to $25 \%$ of $\mathrm{P}$ applied via fertilizer. Therefore, the NPK formulas available on the market contain high P content (Correa, 2004). Fink et al. (2014) quantified that $P$ fixation in the soil can reach up to $4,961 \mathrm{mg} \mathrm{kg}^{-1}$ in a long-term study in Brazilian soils. The low availability of $P$ is also aggravated in the soils cultivated in Cerrado savanna (Brazil), which have high acidity, high aluminum saturation and low base saturation.

It is estimated that the world population will increase by $33 \%$ until 2050, from the current 7.2 billion to 9.6 billion people (Nalley et al., 2017). Therefore, enhancing P fertilizer use efficiency is important to increase the supply of food. Due to the importance of food, economy and environment safety, it is necessary to carry out studies aimed at increasing $P$ fertilizers use efficiency in agriculture.

Several strategies have been used to increase $P$ fertilization efficiency. Lately, the most frequently used strategy has been the application of increased efficiency fertilizers. These fertilizers contain aggregate technologies that control the release of nutrients or stabilize their chemical transformations in the soil, increasing their availability to plants (Association of American Plant Food Control Officials - 
AAPFCO, 1997). This type of technology has long been used in nitrogen fertilizers, but its use in P fertilizers is small. One of the strategies are used in increased nitrogen efficiency of fertilizers is the addition of additives capable of inhibiting the transformation of nitrogen into the soil in some undesirable way (AAPFCO, 1997). A similar strategy could be applied with additives of iron and aluminum affinity, elements responsible for $\mathrm{P}$ fixation in the soil and found in $\mathrm{P}$ fertilizers, increasing their agronomic efficiency. In studies with P fertilizer coated with anionic polymers (Policote), Reis Jr and Silva (2012) and Chagas et al. (2015) demonstrated reduction of iron and aluminum interference and greater availability of $P$ in the soil.

The need to increase $P$ fertilization efficiency and the lack of information on increased efficiency $P$ fertilizers justify studies that evaluate the performance of this type of fertilizers. Considering the importance of the interaction of different soil, region and crop year with $\mathrm{P}$ fertilization, the aims of this study were to evaluate plant growth, foliar $P$ content and yield of soybean and corn crops grown in different seasons and places in response to $P$ rates and sources.

\section{Results and discussion}

\section{Analysis of soybean crop production}

All the characteristics evaluated were significantly influenced by $P$ fertilization in the experiments $(p<0.01)$, except for the foliar $P$ content in the $2010 / 2011$ season, which is consistent with the low soil $P$ availability of experimental areas.

In 2009/2010 and $2010 / 2011$ seasons, $P$ sources ( $p \leq 0.01$ and $p<0.05$; respectively) and rates ( $<0.01$ and $p<0.01$, respectively) influenced the plant height $(\mathrm{PH})$. Plant short height is a typical $P$ deficiency symptom (Gutierrez-Boem and Thomas, 1998). In the 2009/2010 season (Figure 1A), application of MAP, increased PH from $71.8 \mathrm{~cm}$ (without $P$ fertilization) to $85.2 \mathrm{~cm}$ using $120 \mathrm{~kg} \mathrm{P}_{2} \mathrm{O}_{5} \mathrm{ha}^{-1}$. Moreover, application of Policote coated MAP as a source, increased PH up to $90.6 \mathrm{~cm}$ using $101.3 \mathrm{~kg} \mathrm{P}_{2} \mathrm{O}_{5} \mathrm{ha}^{-1}$. In the 2010/2011 season (Figure 1B), the highest $\mathrm{PH}$ was observed at $120 \mathrm{~kg}$ $\mathrm{P}_{2} \mathrm{O}_{5}$ ha $^{-1}$, when Policote coated MAP had a higher $\mathrm{PH}(64.4$ $\mathrm{cm})$ than the MAP $(61.2 \mathrm{~cm})$. The average PHs were $9.65 \%$ and $7.37 \%$ higher in 2009/2010 and 2010/2011 seasons, respectively, when Policote coted MAP was used compared to using MAP only. The highest PH, using MAP as source in both seasons $(85.2 \mathrm{~cm}$ and $61.2 \mathrm{~cm}$ ), were obtained with 120 kg $\mathrm{P}_{2} \mathrm{O}_{5} \mathrm{ha}^{-1}$. The same PHs were obtained using Policote coated MAP in both seasons, with 44.7 and 93.9 of $\mathrm{kg} \mathrm{P}_{2} \mathrm{O}_{5}$ $\mathrm{ha}^{-1}$, respectively, representing $37.5 \%$ and $78.25 \%$ of the phosphorus rate using MAP as source to obtain the same $\mathrm{PH}$.

Leaf $P$ content $(L P C)$ was influenced by $P$ rates $(p<0.05)$ and sources $(p<0.01)$ only in the $2009 / 2010$ season, when LPC increased from $5.35 \mathrm{~g} \mathrm{~kg}^{-1}$ (without $P$ fertilization), up to 5.51 $\mathrm{g} \mathrm{kg}^{-1}$ with $120 \mathrm{~kg} \mathrm{P}_{2} \mathrm{O}_{5} \mathrm{ha}^{-1}$ using MAP, and up to $5.70 \mathrm{~g} \mathrm{~kg}^{-1}$ with $120 \mathrm{~kg} \mathrm{P}_{2} \mathrm{O}_{5} \mathrm{ha}^{-1}$ using Policote coated MAP (Figure 1C). The same LPC was achieved with $120 \mathrm{~kg} \mathrm{P}_{2} \mathrm{O}_{5} \mathrm{ha}^{-1}$ using MAP $\left(5.51 \mathrm{~g} \mathrm{~kg}^{-1}\right)$ and $31.3 \mathrm{~kg} \mathrm{P}_{2} \mathrm{O}_{5} \mathrm{ha}^{-1}$ using Policote coated MAP. This result demonstrates that the Policote coated MAP provided more $\mathrm{P}$ to the plants throughout the crop cycle than conventional MAP. The average LPC in 2010/2011 season was $2.05 \mathrm{~g} \mathrm{~kg}^{-1}$, regardless of $P$ rate and source, which was below the adequate $L P C$ range $\left(2.8\right.$ to $3.6 \mathrm{~g} \mathrm{~kg}^{-1}$ ) for soybean (SBCS/NEPAR, 2017).

Phosphorus fertilization $(p<0.01)$ increased soybean yield in the $2009 / 2010$ and $2010 / 2011$ seasons, with a significant effect of $P$ sources $(p<0.01$ and $p<0.05$, respectively) and rates $(p<0.05$ and $p<0.01$, respectively). In 2009/2010 season, soybean yield increased from $1697 \mathrm{~kg} \mathrm{ha}^{-1}$, without $P$ fertilization, up to $1904 \mathrm{~kg} \mathrm{ha}^{-1}$, using the MAP at $120 \mathrm{~kg}$ $\mathrm{P}_{2} \mathrm{O}_{5}$ ha $^{-1}$, while using Policote coated MAP, the maximum productivity was $2060 \mathrm{~kg} \mathrm{ha}^{-1}$, with $89.8 \mathrm{~kg} \mathrm{P}_{2} \mathrm{O}_{5}$ ha $^{-1}$ (Figure 1E). In 2010/2011 season, soybean yield was increased from $1613.7 \mathrm{~kg} \mathrm{ha}^{-1}$ (without P fertilization), up to $3102.3 \mathrm{~kg} \mathrm{ha}^{-1}$, using MAP with at $120 \mathrm{~kg} \mathrm{P}_{2} \mathrm{O}_{5} \mathrm{ha}^{-1}$, while application of Policote coated MAP produced the maximum yield of 3297.6 $\mathrm{kg} \mathrm{ha}^{-1}$, using $112.1 \mathrm{~kg} \mathrm{P}_{2} \mathrm{O}_{5} \mathrm{ha}^{-1}$ as source (Figure 1F). These results are in agreement with those found by Silva Junior et al. (2008), in which the use of polymer-coated fertilizers resulted in higher soybean yield, when compared to conventional fertilizer.

The recommended soil Phosphorus rate for soybean crop was analyzed in 2009/2010 and 2010/2011 seasons. 81-100 and $101-120 \mathrm{~kg}$ of $\mathrm{P}_{2} \mathrm{O}_{5} \mathrm{ha}^{-1}$ were suggested for expected yield of $3,000-4,000 \mathrm{~kg} \mathrm{ha}{ }^{-1}$ (SBCS/NEPAR, 2017), respectively. Soybean yields with $100 \mathrm{~kg} \mathrm{P}_{2} \mathrm{O}_{5} \mathrm{ha}^{-1}$ and MAP in 2009/2010 and 2010/2011 seasons were 1,869 and 3,021 $\mathrm{kg} \mathrm{ha}^{-1}$, respectively, while using the same $\mathrm{P}$ rate and Policote coated MAP they were 2,056 and $3278 \mathrm{~kg} \mathrm{ha}^{-1}$, respectively, an increase of $10 \%$ and $8.5 \%$, respectively. Better results for plant height and wheat yield with polymers coated fertilizers were also reported by Xiao et al. (2006).

Agronomic P use efficiency (APUE) was higher in 2010/2011 season than 2009/2010 season (Table 5). The lower yield observed in the first season probably occurred due to lower $\mathrm{P}$ conversion in grain production, resulting in lower APUE. The lower levels of $P$ available to plants decrease soybean yield potential, as it caused less flower formation and larger numbers of aborted pods (Ventimiglia et al., 1999). The increasing $P$ fertilization rate resulted in lower APUE, which is associated with the "decreasing increments law", where the successive nutrient supply results in decreasing increments of productivity (Pimentel Gomes, 1990). However, in both trials and at any $P$ rate, there was a higher APUE with Policote coated MAP than with MAP. Ali et al. (2017) also observed increased agronomic efficiency by using polymers coated phosphorus fertilizer. Agronomic efficiency was increase with Policote coated fertilizer and produced higher soybean yield.

\section{Analysis of corn crop production}

All characteristics evaluated were significantly influenced by treatments $(p<0.01)$ except for LPF. The LPC was not influenced by $P$ fertilization, with a mean value of $3.41 \mathrm{~g} \mathrm{~kg}^{-1}$, which is within the adequate range for corn crop (Gott et al., 2014).

Plant height $(\mathrm{PH})$ was influenced only by $\mathrm{P}$ rates $(p<0.01)$. $\mathrm{PH}$ was increased linearly from $1.91 \mathrm{~m}$ (without $\mathrm{P}$ fertilizer) up to $2.09 \mathrm{~m}$, with $160 \mathrm{~kg} \mathrm{P}_{2} \mathrm{O}_{5} \mathrm{ha}^{-1}$ (Figure $2 \mathrm{~A}$ ). Increasing $P$ rates usually promotes higher plant heights (Valadão et al., 2017). This result indicates that the use of phosphate fertilizers, regardless of source, promotes a corn height increase. 
Table 1. Soil chemical characteristics used in the 2009/2010 season, Ponta Grossa.

\begin{tabular}{|c|c|c|c|c|c|c|c|c|}
\hline $\mathrm{pH}$ & C & $P$ & $\mathrm{~K}$ & $\mathrm{Ca}$ & $\mathrm{Mg}$ & $\mathrm{H}+\mathrm{Al}$ & CEC & $\mathrm{V}$ \\
\hline$\left(\mathrm{CaCl}_{2}\right)$ & $\mathrm{g} \mathrm{dm}^{-3}$ & $\mathrm{mg} \mathrm{dm}^{-3}$ & $-\cdots$ & $\mathrm{mol}_{\mathrm{c}} \mathrm{dr}$ & ---- & & & $\%$ \\
\hline 4.1 & 33.20 & 4.1 & 4.1 & 53.0 & 38.0 & 42.8 & 137.9 & 69 \\
\hline
\end{tabular}

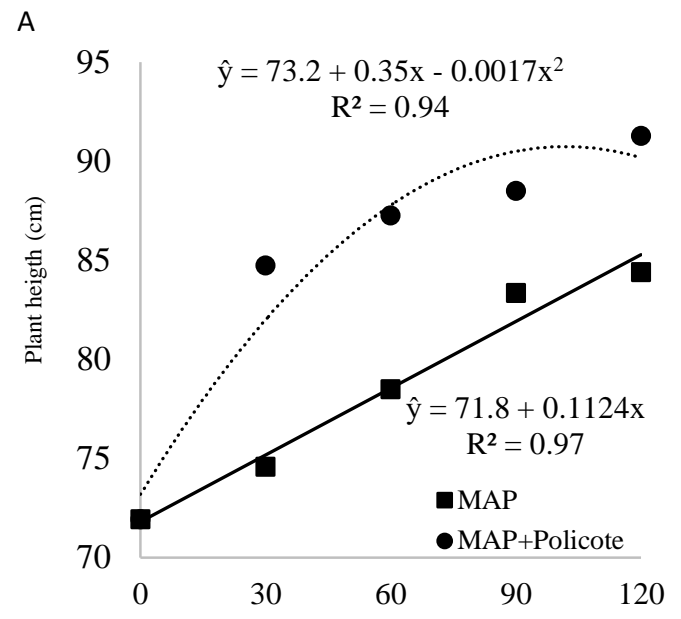

B

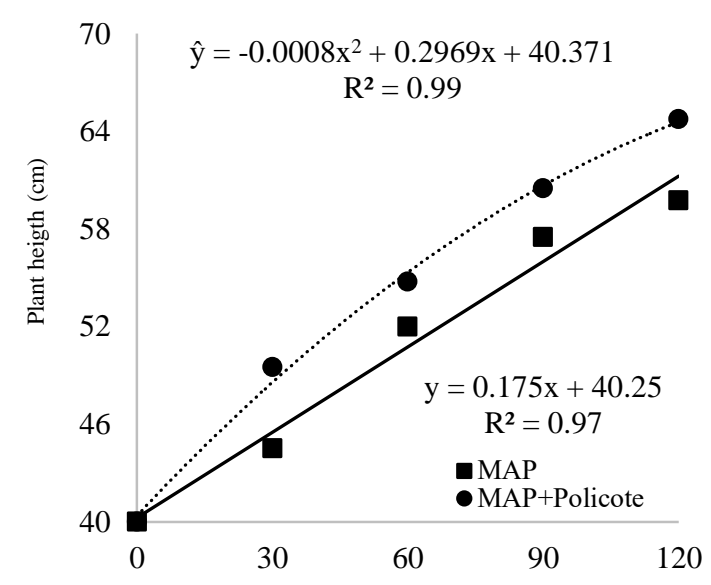

C
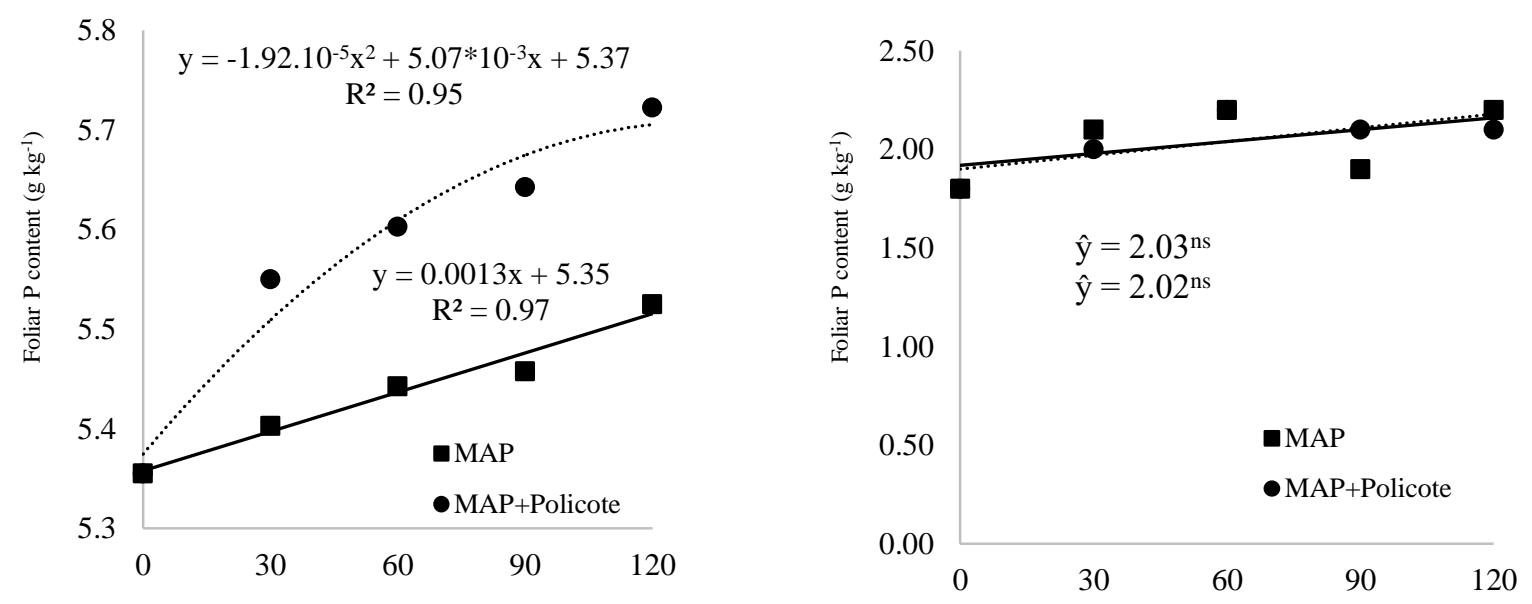

E
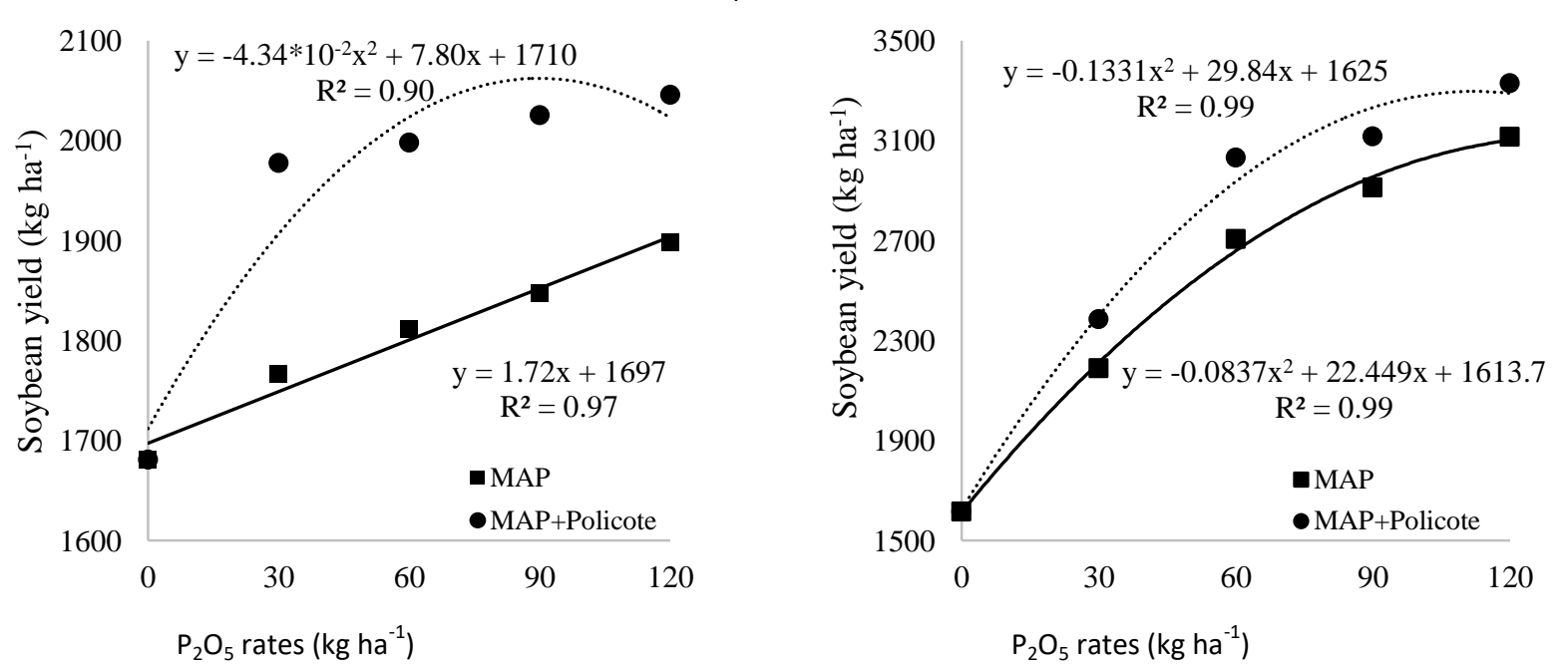

Fig 1. Plant height, foliar $P$ content and soybean yield using phosphorus fertilization at 2009/2010 2009/2010 (A, C and E, respectively); 2010/2011 (B, D, E, respectively) seasons. 
Table 2. Soil chemical characteristics used in the $2010 / 2011$ season, Ponta Grossa.

\begin{tabular}{|c|c|c|c|c|c|c|c|c|c|c|c|c|}
\hline $\mathrm{pH}$ & C & $P$ & $\mathrm{Fe}$ & $\mathrm{Cu}$ & $\mathrm{Mn}$ & $\mathrm{Zn}$ & $\mathrm{K}$ & $\mathrm{Ca}$ & $\mathrm{Mg}$ & $\mathrm{H}+\mathrm{Al}$ & CEC & $\mathrm{V}$ \\
\hline$\left(\mathrm{CaCl}_{2}\right)$ & $\mathrm{g} \mathrm{dm}^{-3}$ & ---- & mg & ${ }^{-3} \mathrm{Zn}-$ & --- & & & $\mathrm{mm}$ & $\mathrm{dm}^{-3} \mathrm{C}$ & 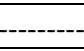 & & $\%$ \\
\hline 4.73 & 45.0 & 0.77 & 83.15 & 2.02 & 42.46 & 3.57 & 3. & 30.5 & 23. & 76.0 & 133.6 & 43 \\
\hline
\end{tabular}

Extractor: P, K - Mehlich-1.

A

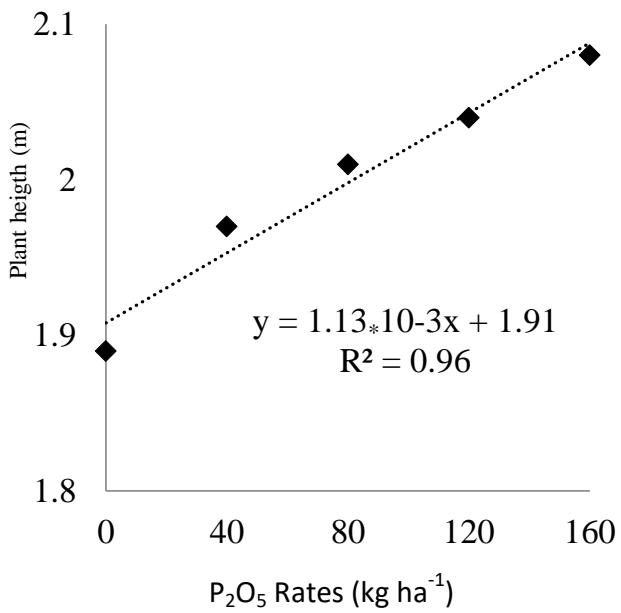

B

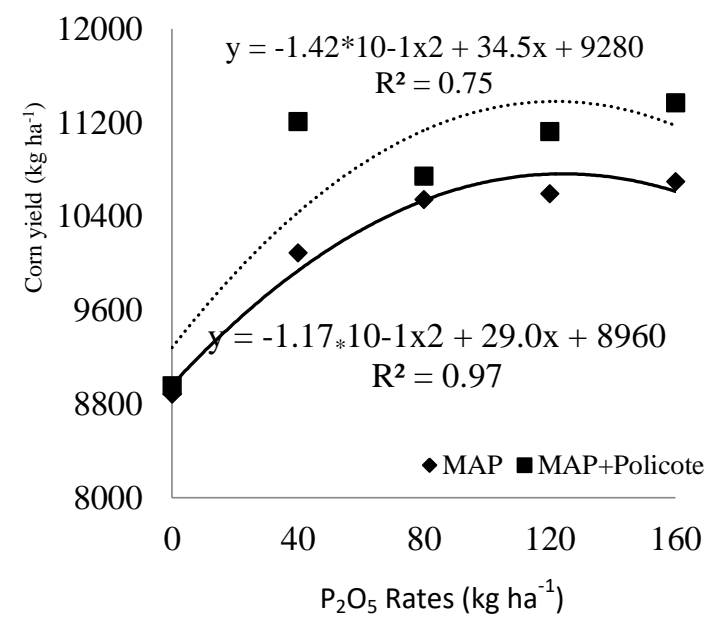

Fig 2. Plant height $(A)$ and corn yield $(B)$ with phosphorus fertilization.

Table 3. Soil chemical characteristics used in the $2013 / 2014$ season, Selvíria.

\begin{tabular}{|c|c|c|c|c|c|c|c|c|c|c|}
\hline $\mathrm{pH}$ & O.M. & $P$ & $\mathrm{~K}$ & $\mathrm{Ca}$ & $\mathrm{Mg}$ & $\mathrm{Al}$ & $\mathrm{V}$ & Clay & Silt & Sand \\
\hline$\left(\mathrm{CaCl}_{2}\right)$ & $\mathrm{g} \mathrm{dm}^{-3}$ & $\mathrm{mg} \mathrm{dm}^{-3}$ & \multicolumn{4}{|c|}{ - $\mathrm{mmol}_{\mathrm{c}} \mathrm{dm}^{-3} \mathrm{Al}$} & --\%-- & ----- & $-\cdots$ & \\
\hline 4.6 & 21.0 & 14 & 2.0 & 9.0 & 9.0 & 5.0 & 32 & 620 & 78 & 302 \\
\hline
\end{tabular}

Extractors: P - Resin; K - Mehlich-1.

Table 4. Description of the treatments evaluated on the experiment and the respective quantities of $\mathrm{P}_{2} \mathrm{O}_{5}$ provided.

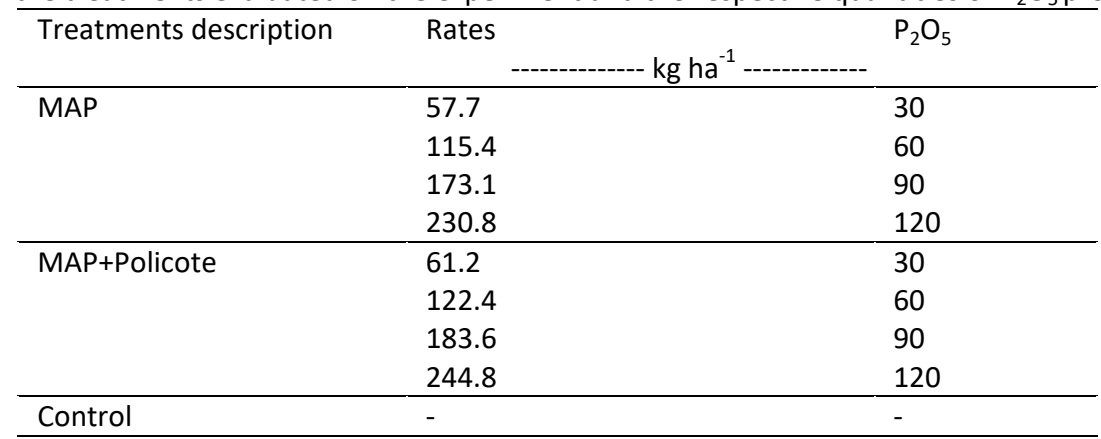

Table 5. Agronomic phosphorus use efficiency (APUE) with P sources and rates at 2009/2010 and 2010/2011 seasons of soybean crop.

\begin{tabular}{|c|c|c|c|c|}
\hline \multirow[b]{3}{*}{ Rates $\left(\mathrm{kg} \mathrm{P}_{2} \mathrm{O}_{5} \mathrm{ha}^{-1}\right)$} & \multicolumn{4}{|c|}{ APUE (kg of harvested Soybean per kg of applied $\mathrm{P}_{2} \mathrm{O}_{5}$ ) } \\
\hline & \multicolumn{2}{|c|}{ 2009/2010 Season } & \multicolumn{2}{|c|}{ 2010/2011 Season } \\
\hline & MAP & MAP+Policote & MAP & MAP+Policote \\
\hline 30 & 2.84 & 9.90 & 19.15 & 25.65 \\
\hline 60 & 2.17 & 5.29 & 18.18 & 23.62 \\
\hline 90 & 1.85 & 3.83 & 14.41 & 16.69 \\
\hline 120 & 1.81 & 3.04 & 12.49 & 14.29 \\
\hline Average & 2.17 & 5.51 & 16.06 & 20.06 \\
\hline
\end{tabular}

Table 6. Agronomic phosphorus use efficiency (APUE) with $\mathrm{P}$ sources and rates in corn crop.

\begin{tabular}{lll}
\hline & APUE $\left(\mathrm{kg}\right.$ of harvested corn per kg of applied $\left.\mathrm{P}_{2} \mathrm{O}_{5}\right)$ \\
Rates $\left(\mathrm{kg} \mathrm{P}_{2} \mathrm{O}_{5} \mathrm{ha}^{-1}\right)$ & MAP & MAP+Policote \\
\hline 40 & 30.13 & 56.34 \\
80 & 20.75 & 22.31 \\
120 & 14.26 & 18.07 \\
160 & 11.32 & 15.06 \\
\hline Average & 19.12 & 27.95 \\
\hline
\end{tabular}


Corn yield was significantly influenced by $P$ sources $(p<0.05)$ and rates $(p<0.01)$. Corn yield was higher with Policote coated MAP than with MAP (Figure 2B). Corn yield increased from $8,960 \mathrm{~kg} \mathrm{ha}^{-1}$, without $P$ fertilization, up to $10,757 \mathrm{~kg}$ $\mathrm{ha}^{-1}$, using MAP with $123.9 \mathrm{~kg} \mathrm{P}_{2} \mathrm{O}_{5} \mathrm{ha}^{-1}$, while using Policote coated MAP produced the maximum yield of $11,375 \mathrm{~kg} \mathrm{ha}^{-1}$, with $121.5 \mathrm{~kg} \mathrm{P}_{2} \mathrm{O}_{5} \mathrm{ha}^{-1}$, a yield increase of $5.7 \%$. The yield of $10,757 \mathrm{~kg} \mathrm{ha}^{-1}$ was obtained using MAP with $123.9 \mathrm{~kg} \mathrm{P}_{2} \mathrm{O}_{5}$ $\mathrm{ha}^{-1}$ or using Policote coated MAP with $43.6 \mathrm{~kg} \mathrm{P}_{2} \mathrm{O}_{5} \mathrm{ha}^{-1}$. Higher corn yield with polymer coated phosphorus was also reported by Silva et al. (2012).

Phosphorus rate recommendation for corn crop at soil used in this trail is $120 \mathrm{~kg} \mathrm{P}_{2} \mathrm{O}_{5} \mathrm{ha}^{-1}$, for an expected yield of about $8,000 \mathrm{~kg} \mathrm{ha}^{-1}$ (Aguiar et al., 2014). Corn yield with $120 \mathrm{~kg}$ $\mathrm{P}_{2} \mathrm{O}_{5} \mathrm{ha}^{-1}$ and MAP was $10,755 \mathrm{~kg} \mathrm{ha}^{-1}$, while using the same $\mathrm{P}$ rate and Policote coated MAP was $11,375 \mathrm{~kg} \mathrm{ha}^{-1}$, an increase of $5.7 \%$.

Increasing $P$ rates resulted in lower APUE (Table 6). However, the APUE was higher with Policote coated MAP than that with MAP at any P rate. Figueiredo et al. (2012) also reported higher corn yields with polymer coated $P$ fertilizer in clay soil. The increase in corn yield using Policote coated MAP was a consequence of the higher agronomic efficiency observed with this source of phosphorus.

Similar results of higher plant growth, productivity and agronomic efficiency with Policote coated $\mathrm{P}$ fertilizer were also observed by Chagas et al. (2015), Chagas et al. (2016) and Guelfi et al. (2018) in lettuce and coffee crops, respectively. Studies of enhanced efficiency fertilizers can bring advantages to several crops, including soybeans and corn that represent important crops for food production.

\section{Materials and methods}

\section{Experimental sites and description}

The experiment was conducted in three field trials. Two soybean trials were carried out in IAPAR experimental area, located in Ponta Grossa, PR, Brazil and one corn trial was carried out in Unesp Ilha Solteira experimental area, located in Selvíria, MS, Brazil. Ponta Grossa is located in Parana State, Brazil, the coordinates are latitudes of 2500'54" $S$ and longitudes of 50.9'12" W and average altitude around 975 $\mathrm{m}$. According to Köppen international classification, the climate of the region is $\mathrm{Cfb}$, with average temperature of $17.5^{\circ} \mathrm{C}$ and average precipitation of $1495 \mathrm{~mm}$.

And Selvíria is located in Mato Grosso do Sul State, Brazil, presenting as geographical coordinates of $20^{\circ} 20^{\prime} 51.44^{\prime \prime} \mathrm{S}$ and $51^{\circ} 24^{\prime} 11.10^{\prime \prime} \mathrm{W}$ and average altitude around $335 \mathrm{~m}$. The climate of the region is Aw, defined as tropical humid with rainy season in summer and dry in winter, according to the international classification of Köeppen, presenting temperature, precipitation and average annual relative humidity of $24.5^{\circ} \mathrm{C}, 1370 \mathrm{~mm}$ and $64.8 \%$, respectively.

In Ponta Grossa, trials were conducted in two crop seasons, the first in 2009/2010 and the other in 2010/2011. Soils in the experimental areas were classified as dystrophic Red Latosol (Santos et al., 2014), with a clay texture. The chemical characteristics of soil used in the 2009/2010 and 2010/2011 seasons are presented Tables 1 and 2, respectively. A trial was conducted in Selvíria in the $2013 / 2014$ season, where the soil was classified also as a dystroferric Red Latosol, with clayey texture (Santos, 2014).
The chemical characteristics of the soil in the experimental area were given in Table 3.

Although the studied soils presented similar textures, but differences between their chemical attributes, mainly in relation to the basis saturation, were observed. In addition, there were differences between the climate and relief that can influences the phosphorus absorption and crop production, what justifies the experiment in different places. The variation of grain yield in one crop year to another justifies the experiment in distinct seasons.

\section{Sources of $P$ used in the experiment}

The monoammonium phosphate (MAP) and Policote coated MAP (Policote+MAP) were used as sources of P. Monoammonium phosphate is a common granular fertilizer with a high $\mathrm{P}$ content that also contains nitrogen (N) (Robertson et al., 2012). The one used in this study contains $52 \%$ of $\mathrm{P}_{2} \mathrm{O}_{5}$ and $11 \%$ of $\mathrm{N}$. Policote is an additive based on water-soluble polymers marketed by Wirstchat Polímeros do Brasil. Polite+MAP contains $10 \%$ of $\mathrm{N}$ and $49 \%$ of $\mathrm{P}_{2} \mathrm{O}_{5}$. We applied four rates of these sources in order to provide 30, 60,90 and $120 \mathrm{~kg} \mathrm{P}_{2} \mathrm{O}_{5} \mathrm{ha}^{-1}$. The final quantities are presented in Table 4.

\section{Trial conduction of soybean}

The treatments applied in the sowing furrow were arranged in a factorial $(2 \times 4)+1$, using two P sources (MAP - $11 \% \mathrm{~N}$, $52 \% \mathrm{P}_{2} \mathrm{O}_{5}$ and Policote coated MAP - 10\% N, 49\% $\mathrm{P}_{2} \mathrm{O}_{5}$ ), four $P$ rates $\left(30,60,90\right.$ and $120 \mathrm{~kg} \mathrm{P}_{2} \mathrm{O}_{5} \mathrm{ha}^{-1}$ ) and control (without application of $\mathrm{P}$ fertilizer). A randomized block design with four replications was used.

In each experiment, the plot studied was formed by eight 6 $\mathrm{m}$-long lines, with $0.45 \mathrm{~m}$ row spacing. The four central rows were considered useful area, and two meters were cleared from the extremities. The COODETEC 232 variety was sown in December 5th, 2009, while the BRS 184 variety at November 12th, 2010. Potassium fertilizer (KCl; $80 \mathrm{~kg} \mathrm{~K} \mathrm{~K}_{2} \mathrm{O}$ $\mathrm{ha}^{-1}$ ) was applied 25 days after plant emergence (DAE). The cultural treatments were carried out following technical recommendations for that culture.

Plant height, number of pods per plant, leaf $\mathrm{P}$ content and productivity were evaluated. In the $2009 / 2010$ season the height of plants was evaluated in the R3 stage, while in the 2010/2011 season that evaluation was done at soybean harvest. Ten plants were randomly collected from each plot at harvest to determine the number of pods per plant. In order to determine the leaf $\mathrm{P}$ content, the third trifolium (with petiole) was sampled in full bloom. The leaves were then washed in distilled water and oven dried with forced air circulation at $65^{\circ} \mathrm{C}$ for 72 hours. The leaves were then milled in Wiley type mill, with a $0.84 \mathrm{~m}$ mesh sieve. The dry matter was mineralized by the nitric-perchloric mixture $\left(3: 1 \vee v^{-1}\right)$, determining the $\mathrm{P}$ content by colorimetry. The plots were mechanically harvested, and productivity was determined in the useful area of each plot in $\mathrm{kg} \mathrm{ha}^{-1}$ (13\% wet basis).

\section{Trial of corn cultivation}

The treatments, applied to the sowing furrow, were arranged in a factorial $(2 \times 5)$, with two $P$ sources (MAP and Policote coated MAP) and five $P$ rates $(0 ; 40,80,120$ and 
$160 \mathrm{~kg} \mathrm{P}_{2} \mathrm{O}_{5} \mathrm{ha}^{-1}$ ). A randomized block design with four replications was used.

The experimental plot was formed by seven $6 \mathrm{~m}$-long lines, with $0.45 \mathrm{~m}$ row spacing. The three central rows were considered as useful area and $0.5 \mathrm{~m}$ was cleared from the extremities. The treatments, together with $30 \mathrm{~kg} \mathrm{~N}+70 \mathrm{~kg}$ $\mathrm{K}_{2} \mathrm{O} \mathrm{ha}^{-1}$ of urea and $\mathrm{KCl}$ as sources, respectively, were applied on November $6^{\text {th }}, 2013$. The urea rates applied at sowing considered the $\mathrm{N}$ contribution of the fertilizers in the treatments, so that all treatments received only $30 \mathrm{~kg} \mathrm{~N} \mathrm{ha}^{-1}$ at sowing.

Soon after the treatments, the hybrid Dow $2 \mathrm{~B} 710$ PW were seeded. The experiment was conducted according to the practices recommended for this crop. Ammonium sulfate $\left(50 \mathrm{~kg} \mathrm{~N} \mathrm{ha}^{-1}\right)$ and zinc sulfate $\left(2 \mathrm{~kg} \mathrm{Zn} \mathrm{ha}{ }^{-1}\right)$ fertilization were carried out when the plants had 4 to 5 expanded leaves and urea fertilization ( $50 \mathrm{~kg} \mathrm{~N} \mathrm{ha}^{-1}$ ) was carried out when the plants had 7 to 8 expanded leaves, with posterior irrigation $(15 \mathrm{~mm})$ in order to avoid losses by nitrogen volatilization. At $45 \mathrm{DAE}, 10$ plants per plot were randomly collected to evaluate plant height. Corn ear leaf was sampled to evaluate P foliar content, as described for the soybean experiment. The plots were mechanically harvested, and productivity was determined in the useful area of each plot in $\mathrm{kg} \mathrm{ha}^{-1}(13 \%$ wet basis).

\section{Statistical analysis}

The data were submitted to analysis of variance and regression. The effect of $P$ sources and rates were only analyzed when there was a statistically significant difference between treatments. The highest coefficient of determination model $\left(R^{2}\right)$ and biological logic were chosen. Statistical analyzes were performed using the Assistat program (Silva and Azevedo, 2016). With the average yields of $P$ sources and rates, agronomic $P$ use efficiencies were calculated using the equation proposed by Fageria (2005).

\section{Conclusion}

Phosphorus fertilization increased soybean and corn plant heights and yields in different seasons and places. Soybean and corn yield and agronomic phosphorus use efficiency were higher with Policote coated phosphorus fertilizer compared to conventional phosphorus fertilizer. Policote coated phosphorus fertilizer can be used as an enhanced efficiency fertilizer because it increased soybean and corn yields in different seasons and places.

\section{References}

Ali I, Mustafa A, Vaseen M, Imran M (2017) Polymer coated dap helps in enhancing growth, yield and phosphorus use efficiency of wheat (Triticum aestivum L.). J Plant Nutr. 40: 2587-2594.

ASSOCIATION OF AMERICAN PLANT FOOD CONTROL OFFICIALS - AAPFCO. Official documents 57. West Lafayette: AAPFCO, 1997.

Chagas WFT, Emrich EB, Guelfi DR, Caputo ALC, Faquin V (2015) Productive characteristics, nutrition and agronomic efficiency of polymer-coated MAP in lettuce crops. Rev Cienc Agron. 46: 266-275.
Chagas WFT, Guelfi DR, Caputo ALC, Dominghetti AW, Faquin V, Lopes RM, Chagas RMR (2016) Eficiência agronômica do superfosfato triplo revestido por polímeros no crescimento inicial do cafeeiro. Coffee Sci. 11: 427-435.

Correa JC, Mauad M, Rosolem CA (2004) Fósforo no solo e desenvolvimento de soja influenciados pela adubação fosfatada e cobertura vegetal. Pesqui Agropecu Bras. 39: 1231-1237.

Dorahy, CG, Rochester IJ, Blair GJ, Till AR (2008) Phosphorus Use-Efficiency by Cotton Grown in an Alkaline Soil as Determined Using 32 Phosphorus and 33 Phosphorus Radio-Isotopes. J Plant Nutr. 31: 1877-1888.

Fardeau JC (1996) Dynamics of phosphate in soils: an isotopic outlook. Fer Res. 45: 91-100.

Figueiredo CC, Barbosa DV, Oliveira AS, Fagioli M, Sato JH (2012) Adubo fosfatado revestido com polímero e calagem na produção e parâmetros morfológicos de milho. Rev Cien Agron. 43: 446-452

Fink JR, Inda AV, Bayer C, Torrent J, Barro NV (2014) Mineralogy and phosphorus adsorption in soils of south and central-west Brazil under conventional and no-tillage systems. Act SciAgron. 36: 379-387.

Gott RM, Aquino LA, Carvalho AMX, Santos, LPD, Nunes PHMP, Coelho BS (2014) Índices diagnósticos para interpretação de análise foliar do milho. Rev Bras Engen Agric Ambien, 18: 1110-1115.

Guelfi DR, Chagas WFT, Lacerda JR, Chagas RMR, Souza TL, Andrade $A B$ (2018) Monoammonium phosphate coated with polymers and magnesium for coffee plants. Cien e Agrotec. 42:261-270.

Gutierrez-Boem FH, Thomas GW (1998) Phosphorus nutrition and water deficits in field-grown soybeans. Plant Soil. 207:87-96.

Murphy L, Sanders L (2007) Improving N and P use efficiency with polymer technology. Vyn, T. (ed.) Indiana CCA Conference Proceedings. p. 1-13. 2007.

Nalley L, Tack J, Durand A, Thoma G, Tsiboe T, Ashew A, Barkley A (2017) The Production, Consumption, and Environmental Impacts of Rice Hybridization in the United States. AgronJ. 9: 193-203.

Pimentel Gomes F (1990) O índice de variação: um substituto vantajoso do coeficiente de variação. Piracicaba: Ipef.

Raij BV (2011) Fertilidade do solo e manejo de nutrientes. Piracicaba, International Plant Nutrition Institute.

Reis Junior RA, Silva DRG (2012) Avaliação das características físicas e físico químicas de fertilizantes nitrogenados e fosfatados revestidos por polímeros. Magistra. 24: 145150.

Robertson E, Ketterings Q, Hunter M, Czymmek K, Kilcer C (2012) Phosphorus sources for field crops. Agronomy Fact Sheet Series, Fact Sheet 73. Cornell University.

Sanders JL, Murphy LS, Noble A, Melgar RJ, Perkins J (2012) Improving phosphorus use efficiency with polymer technology. Procedia Engineer. 46: 178--184.

Santos HG, Jacomine PKT, Anjos LHC, Oliveira VA, Lubreras JF, Coelho MR, Almeida JA, Cunha TF, Oliveira JB eds. (2014). Sistema brasileira de classificação de solos. 4 ed. Brasília, Embrapa.

SCBS/NEPAR - Sociedade Brasileira de Ciência do Solo/Núcleo Estadual Paraná. Manual de adubação e calagem para o Estado do Paraná (2017) Curitiba, Sociedade Brasileira de Ciência do solo. 
Silva AA, Silva TS, Vasconelos ACP, Lana RMQ (2012) Influencia da aplicação de diferentes fontes de MAP revestido com polímeros de liberação gradual na cultura do milho. Biosci J. 28: 240-250.

Silva Junior HR, Lima RE, Perin A (2008) Adubação fosfatada com fertilizantes polimerizados na cultura da soja. In: Jornada Da Produção Cientifica Da Educação Profissional E Tecnológica Da Região Centro-Oeste, Cuiabá.

Silva FAZ, Azevedo CAV (2016) The Assistat Software Version 7.7 and its use in the analysis of experimental data. Afr. J. Agric. Res. 11: 3733-3740.

Taiz L, Zeiger E (2009) Fisiologia Vegetal. 4. Ed. Porto Alegre, Artmed.
Takashi S, Anwar MR (2007) Wheat grain yield, phosphorus uptake and soil phosphorus fraction after 23 years of annual fertilizer application to an Andosol. Field Crop Res. 101:160-171.

Valadão FCA, Weber OLS, Júnior DDV, Santin MFM, Scapinelli A (2017) Teor de macronutrientes e produtividade da soja influenciados pela compactação do solo e adubação fosfatada. RevCien Agrs. 40: 183-195.

Ventimiglia LA, Costa JÁ, Thomas AL, Pires JLF (1999) Potencial de rendimento da soja em razão da disponibilidade de fósforo no solo e dos espaçamentos. Pesqui Agropecu Bras. 34: 195-199.

Xiao Q, Zhang F, Wang Y, Zhang J, Zhang S (2006) Effects of slow/controlled-release fertilizer cemented and coated by nano-materials on biology. Nanoscience. 11: 18-26. 